\title{
Model Penyelenggaraan Pendidikan Inklusif bagi Penyandang Disabilitas Intelektual: Studi Kasus di DKI Jakarta
}

Indonesian Journal of Religion and Society, 2019, Vol. 01 (01), 66-79

(c) The Journal, 2019

www.journal.lasigo.org/index.php/IJRS

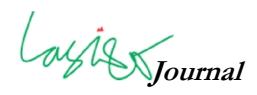

Article History

Received : May, $9^{\text {th }} 2019$

Revised : June, $22^{\text {nd }} 2019$

Accepted : June, 23 2019

\author{
Emilia Kristiyanti \\ Universitas Indonesia, Jakarta, Indonesia \\ emilia.kristiyanti@gmail.com
}

\begin{abstract}
This study aims to develop a model for the implementation of inclusive education for people with intellectual disabilities in DKI Jakarta. As a region that has local regulations on the protection of persons with disabilities, DKI Jakarta government has not yet been able to ensure the fulfillment of the education rights of children with intellectual disabilities. This study used a single instrumental case study approach and was carried out in DKI Jakarta. Data collection is done through in-depth interviews and textual analysis. The results show that social exclusion occurs because of cultural barriers due to stigma, labeling, prejudice, stereotypes, and structural barriers due to discriminatory policies. Both of barriers can be reduced by organizing inclusive education for persons with intellectual disabilities. The model for implementing inclusive education developed not only focuses on developing the life skills of individuals with intellectual disabilities, but also strengthening and developing the surrounding environment and society. Thus, children with intellectual disabilities can be independent and participate in society.
\end{abstract}

Keywords: social exclusion; children intellectual disability; inclusive education.

\begin{abstract}
ABSTRAK
Penelitian ini bertujuan untuk mengembangkan model penyelenggaraan pendidikan inklusif bagi penyandang disabilitas intelektual di DKI Jakarta. Sebagai daerah yang memiliki PERDA perlindungan penyandang disabilitas, pemerintah DKI Jakarta belum mampu memastikan pemenuhan hak pendidikan penyandang disabilitas intelektual. Penelitian ini menggunakan pendekatan studi kasus instrumental tunggal dan dilaksanakan di DKI Jakarta. Pengumpulan data dilakukan melalui interview mendalam dan review dokumentasi. Penelitian menunjukkan bahwa eksklusi sosial terjadi karena adanya hambatan kultur akibat stigma, labelisasi, prasangka, stereotip, dan hambatan struktur akibat kebijakan yang diskriminatif. Kedua hambatan dapat dihilangkan dengan cara menyelenggarakan pendidikan inklusif bagi penyandang disabilitas intelektual yang tidak hanya berfokus kepada pengembangan keterampilan hidup individu penyandang disabilitas intelektual, namun juga penguatan dan pengembangan lingkungan dan masyarakat sekitar, sehingga anak penyandang disabilitas intelektual dapat mandiri dan berpartisipasi dalam masyarakat.
\end{abstract}

Kata Kunci: eksklusi sosial; penyandang disabilitas intelektual; pendidikan inklusi

Corresponding Author:

Name : Emilia Kristiyanti

Email : emilia.kristiyanti@gmail.com 


\section{Pendahuluan}

Bentuk disabilitas yang sangat menonjol tetapi sering tidak terlihat adalah disabilitas intelektual, yang berjumlah kurang lebih $2 \%$ dari total jumlah penyandang disabilitas yang ada (Scior \& Werner, 2016). Pada hakikatnya, kondisi disabilitas secara umum tidak semata-mata tentang hambatan yang dimiliki individu, namun kondisi tersebut lebih disebabkan oleh hambatan yang berasal dari lingkungan sosial mereka (United Nation Convention on Rights of People with Disability, 2006).

Di Indonesia, sekitar 48\% dari satu koma enam juta anak penyandang disabilitas atau sekitar kurang lebih 768.000 anak diduga sebagai anak penyandang disabilitas intelektual yang terbagi dalam kategori ringan, sedang, maupun berat (Badan Pusat Statistik, 2015). Dari jumlah tersebut, hanya kurang lebih $11 \%$ atau 85,000 anak penyandang disabilitas intelektual tersebut dapat bersekolah di sekolah luar biasa (SLB) dan sekolah penyelenggara pendidikan inklusif (Kemendikbud, 2018).

Provinsi DKI Jakarta belum memiliki data yang valid tentang jumlah penyandang disabilitas intelektual. Namun prevalensi yang dapat dipergunakan untuk menghitung jumlah penyandang disabilitas intelektual di DKI Jakarta adalah sekitar 1-3\% dari jumlah penduduk (Salmiah, 2010). Mengacu pada perhitungan prevelansi tersebut maka diperkirakan jumlah anak usia 5-19 tahun penyandang disabilitas intelektual di DKI Jakarta adalah sekitar 68.529 anak. Di tahun 2018, dinas pendidikan DKI Jakarta menyatakan bahwa hanya 5781 atau $8 \%$ dari total anak penyandang disabilitas intelektual di DKI Jakarta yang dapat bersekolah baik di sekolah luar biasa maupun sekolah penyelenggara pendidikan inklusif.

Hal demikian tentunya merupakan fenomena yang dapat menggambarkan betapa akses dan kesempatan penyandang disabilitas intelektual ke pendidikan masih sangat terbatas. Untuk mengatasi permasalahan akses dan kesempatan ini maka muncullah pendidikan inklusif. Munculnya sistem pendidikan inklusif membuka kesempatan bagi para penyandang disabilitas intelektual tersebut untuk dapat bersekolah di sekolah umum bersama anak-anak lain. Namun pada pelaksanaannya, anak penyandang disabilitas intelektual masih mendapat perlakukan yang cenderung diskriminatif meskipun mereka telah bersekolah di sekolah yang menyelenggarakan pendidikan inklusif di DKI Jakarta.

Beberapa hal tersebut diatas yang telah mendorong peneliti untuk menemukan sebuah model penyelenggaraan pendidikan inklusif yang tepat bagi penyandang disabilitas intelektual sehingga eksklusi sosial di pendidikan dapat dihilangkan. Model penyelenggaraan pendidikan inklusif bagi penyandang disabilitas intelektul yang dikembangkan akan mengkapasitasi dua pihak: (1) penyandang disabilitas intelektual; dan (2) lingkungan sosial individu penyandang disabilitas intelektual.

\section{Kerangka Teori \& Konsep}

\subsection{Eksklusi Sosial}

Istilah eksklusi sosial berasal dari Perancis. Pada awalnya, istilah ini mengacu kepada individu yang tidak tercakup oleh sistem keamanan sosial. Istilah eksklusi sosial semakin berkembang sehingga akhirnya mengacu kepada kelompok-kelompok yang termarginalkan seperti para gelandangan dan remaja yang sakit.

Eksklusi sosial merupakan sebuah proses yang kompleks dan multi dimensi. Eksklusi sosial juga merupakan sebuah proses dinamis dari pengucilan individu dari sistem sosial, ekonomi, politik, dan budaya yang menentukan integrasi sosial seseorang dalam masyarakat (Walker, A. and Walker, 1997). Proses tersebut meliputi kekurangan atau penolakan atas sumber daya, hak, barang dan jasa, serta ketidakmampuan individu atau kelompok untuk berpartisipasi dalam hubungan dan kegiatan normal, yang tersedia untuk sebagian besar orang dalam suatu masyarakat, baik di bidang ekonomi, sosial, budaya maupun politik. Berbagai akses hanya tersedia bagi mayoritas kelompok baik dalam ranah ekonomi, sosial, budaya, dan politik. Keadaan ini tentu saja memengaruhi kualitas hidup individu dan kesetaraan serta kohesi masyarakat secara keseluruhan. (Levitas et al., 2007). Bagi Levitas (2007), ekslusi sosial dapat digambarkan sebagai partisipasi sosial yang tidak 
memadai, kurangnya integrasi dan kurangnya power. Konsep ekslusi sosial dapat menjelaskan sejauh mana hak-hak ditolak dan membuat kelompok menjadi terekslusikan.

Teori eksklusi sosial tepat dipergunakan untuk menganalisa pemenuhan hak pendidikan penyandang disabilitas intelektual di DKI Jakarta. Jika dibandingkan dengan kelompok penyandang disabilitas lain dan kelompok non-disabilitas, maka penyandang disabilitas intelektual masih sering kali mengalami pengucilan dari kehidupan sosial yang mengakibatkan mereka tidak memperoleh hak dan tidak dapat berpartisipasi dalam berbagai bidang kehidupan di masyarakat termasuk pendidikan.

\subsection{Disabilitas Intelektual}

Istilah disabilitas intelektual banyak dipergunakan oleh kalangan kesehatan (medis). Istilah disabilitas intelektual (DI) dipergunakan untuk mengganti istilah mental retardation atau retardasi mental karena istilah ini dianggap lebih humanis. Istilah disabilitas intelektual menggambarkan kapasitas dan fungsi yang dapat dijalankan oleh individu. Penyandang disabilitas intelektual berfokus kepada tiga kriteria utama yaitu (1) ketidakberfungsian/hambatan pada intelektual (kognitif) yang ditunjukkan oleh IQ yang ada pada kisaran 70; (2) ketidakmampuan individu untuk melakukan fungsi adaptasi dengan lingkungan sekitar (sosial); dan (3) keadaan tersebut ditemukan atau dikenali atau muncul pada saat individu tersebut berusia di bawah 18 tahun (APA, 2000).

Disabilitas intelektual yang didiskusikan pada artikel ini mengacu kepada pemahaman yang dipergunakan saat ini. Penjelasan tentang teori disabilitas intelektual diperlukan untuk menghindari terjadinya kesalahan penggunaan istilah disabilitas intelektual yang sering kali dianggap sama dengan disabilitas mental.

\subsection{Stigma}

Stigma merupakan reaksi seseorang yang merusak identitas orang lain (Goffman, 1963). Kelompok dominan memiliki potensi yang kuat untuk menentukan pihak-pihak yang akan distigmatisasi. Stigma kemudian menghambat seseorang untuk mendapatkan social power. Stigma pada umumnya akan muncul bersamaan dengan stereotip, labelisasi, dan prasangka. Hal tersebut akan menyebabkan hilangnya status dan diskriminasi bagi orang atau kelompok yang menjadi korban stigma (Link, Bruce G; Phelan, 2001; S. Werner \& Abergel, 2017). Stigma, stereotip, labelisasi, dan prasangka telah menyebabkan diskriminasi perlakuan terhadap penyandang disabilitas dan mengakibatkan mereka tereksklusi dalam berbagai bidang kehidupan di masyarakat termasuk bidang pendidikan. penggunaan stigma dalam artikel ini adalah untuk menganalisa penyebab eksklusi sosial di pendidikan yang masih dialami oleh penyandang disabilitas intelektual secara kultur atau horizontal dan struktur atau vertikal.

\subsection{Pendidikan Inklusi}

Pendidikan inklusif merupakan sistem pendidikan yang memberikan kesempatan pembelajaran yang bermakna bagi semua anak dalam sekolah regular (UNICEF, 2013). Pada sistem pendidikan inklusif, anak penyandang disabilitas merupakan bagian yang tidak terpisahkan dengan lingkungan pendidikan umum (Alshemari, 2016). Pendidikan inklusif berfokus kepada menghilangkan semua hambatan untuk belajar, dan meningkatkan partisipasi anak di pendidikan terutama peserta didik yang rentan terhadap tindak eksklusi dan marginalisasi. Pendidikan inklusif merupakan pendekatan strategis yang dirancang untuk memfasilitasi keberhasilan belajar semua anak. Pendidikan inklusi menjawab permasalahan bersama dan mengurangi serta mengatasi eksklusi di pendidikan, setidaknya di tingkat pendidikan dasar. Pendidikan inklusi juga meningkatkan akses, partisipasi dan keberhasilan pembelajaran dalam pendidikan dasar yang berkualitas untuk semua (UNESCO, 1998).

Pembahasan teori pendidikan inklusi sebagai dasar untuk mengembangkan model penyelenggaraan akan berfokus kepada penyandang disabilitas terutama penyandang disabilitas intelektual. Beberapa strategi yang diterapkan dalam model penyelenggaraan pendidikan inklusif diharapkan mampu menghilangkan stigma serta meningkatkan 
partisipasi penyandang disabilitas intelektual. Salah satu aspek kehidupan yang penting yaitu pendidikan.

\section{Metode Penelitian}

Penelitian ini menggunakan pendekatan kualitatif dengan jenis studi kasus instrumental tunggal. Unit analisa dari penelitian ini adalah sekolah atau organisasi yang berada di provinsi DKI Jakarta. Untuk kepentingan penelitian, maka dipilih salah satu sekolah menengah pertama (SMP) di Jakarta Selatan yang memiliki cukup banyak siswa penyandang disabilitas intelektual dan telah cukup lama menyelenggarakan pendidikan inklusif, satu sekolah menengah atas (SMA) di Jakarta Pusat yang baru memulai menyelenggarakan pendidikan inklusif namun telah memiliki siswa penyandang disabilitas intelektual, dan satu sekolah menengah kejuruan (SMK) negeri yang banyak memiliki siswa penyandang disabilitas intelektual dan telah cukup lama menyelenggarakan pedidikan inklusif.

Informan penelitian yang dilibatkan dalam penelitian ini terbagi menjadi dua, yaitu: informan inti dan informan tambahan. Total informan dari penelitian ini adalah Sembilan belas orang yang terdiri dari sepuluh orang informan inti dan enam orang informan tambahan. Jabatan, kriteria, dan detail jumlah untuk informan inti dan tambahan dapat dilihat pada tabel 1.

Tabel 1. Kategori, Jabatan, dan Kriteria Informan

\begin{tabular}{|c|c|c|c|}
\hline Kategori & Jabatan & Kriteria & Jumlah \\
\hline \multirow{3}{*}{$\begin{array}{l}\text { Informan } \\
\text { Inti }\end{array}$} & $\begin{array}{l}\text { Dinas Pendidikan } \\
\text { DKI Jakarta }\end{array}$ & & 1 orang \\
\hline & $\begin{array}{l}\text { Kepala sekolah } \\
\text { penyelenggara } \\
\text { pendidikan } \\
\text { inklusif atau } \\
\text { wakil }\end{array}$ & $\begin{array}{l}\text { 1. Memimpin sekolah yang } \\
\text { memiliki peserta didik } \\
\text { penyandang disabilitas } \\
\text { intelektual; } \\
\text { 2. Telah menjabat minimal dua } \\
\text { tahun; }\end{array}$ & $\begin{array}{l}2 \text { orang (1 SMP, dan } 1 \\
\text { SMK) }\end{array}$ \\
\hline & Guru & $\begin{array}{l}\text { 1. Guru kelas atau guru mata } \\
\text { pelajaran; } \\
\text { 2. Memiliki peserta didik } \\
\text { penyandang disabilitas } \\
\text { intelektual. }\end{array}$ & $\begin{array}{l}3 \text { orang ( } 2 \text { guru SMP, } 1 \\
\text { guru SMA, dan } 1 \text { guru } \\
\text { SMK). }\end{array}$ \\
\hline \multirow{4}{*}{$\begin{array}{l}\text { Informan } \\
\text { Inti }\end{array}$} & $\begin{array}{l}\text { Pimpinan } \\
\text { organisasi }\end{array}$ & & \\
\hline & $\begin{array}{l}\text { penyandang } \\
\text { disabilitas atau } \\
\text { yang mewakili }\end{array}$ & $\begin{array}{l}\text { 1. Memiliki pengetahuan } \\
\text { tentang anak penyandang }\end{array}$ & 1 orang \\
\hline & $\begin{array}{l}\text { Pimpinan pusat } \\
\text { sumber } \\
\text { pendidikan } \\
\text { inklusif atau yang } \\
\text { mewakili }\end{array}$ & $\begin{array}{l}\text { disabilitas intelektual; } \\
\text { 2. Memiliki pengetahuan } \\
\text { tentang pendidikan inklusif. }\end{array}$ & 1 orang \\
\hline & $\begin{array}{l}\text { Perwakilan orang } \\
\text { tua }\end{array}$ & $\begin{array}{l}\text { Memiliki anak penyandang } \\
\text { disabilitas intelektual }\end{array}$ & 2 orang \\
\hline \multirow{2}{*}{$\begin{array}{l}\text { Informan } \\
\text { Pendukung }\end{array}$} & $\begin{array}{l}\text { Anak penyandang } \\
\text { disabilitas } \\
\text { intelektual }\end{array}$ & Dapat berkomunikasi; & $\begin{array}{l}4 \text { orang ( } 2 \text { laki-laki dan } 2 \\
\text { perempuan) perwakilan } \\
\text { SMP dan SMA/SMK }\end{array}$ \\
\hline & $\begin{array}{l}\text { Anak bukan } \\
\text { penyandang } \\
\text { disabilitas } \\
\text { intelektual }\end{array}$ & $\begin{array}{l}\text { 1. Usia } 13 \text { s.d } 18 \text { tahun; } \\
\text { 2. Memiliki teman dengan } \\
\text { disabilitas intelektual. }\end{array}$ & $\begin{array}{l}6 \text { orang ( } 3 \text { laki-laki dan } 3 \\
\text { perempuan) perwakilan } \\
\text { SMP dan SMA/SMK }\end{array}$ \\
\hline
\end{tabular}

Teknik pengumpulan data yang dipergunakan adalah wawancara mendalam (in depth interview), observasi, dan review dokumentasi. Data-data yang dipergunakan dibagi menjadi data sekunder dan primer. Data sekunder merupakan data-data yang didapat dari pihak ketiga seperti misalnya laporan program, data tentang jumlah penyandang disabilitas intelektual di DKI Jakarta dari Badan Pusat Statistik (BPS) dan lain sebagainya. 
Sedangkan data primer merupakan data yang diperoleh dari hasil wawancara mendalam dan observasi.

\section{Eksklusi Sosial Bagi Penyandang Disabilitas Intelektual di Bidang Pendidikan}

Permasalahan yang dialami oleh penyandang disabilitas intelektual tidak hanya berkisar pada area kognitif dan kemampuan beradaptasi, namun juga terdapat pada hubungan timbal balik (interaksi) dengan keluarga dan masyarakat (Roslina \& Rahayu, 2018). Hal tersebut menjadi pemicu terjadinya eksklusi sosial di pendidikan bagi penyandang disabilitas intelektual. Berdasarkan pandangan model medis (medical model), maka penyandang disabilitas merupakan sasaran rehabilitasi medis. Namun, apabila kita menggunakan perspektif sosial (social model), maka pembenahan yang harus dilakukan berada pada lingkungan sekitar penyandang disabilitas intelektual, baik keluarga maupun masyarakat. Anak-anak penyandang disabilitas intelektual dengan jumlah yang relatif besar di kalangan kelompok disabilitas sendiri merupakan kelompok yang paling rentan tereksklusikan dari berbagai layanan publik termasuk kesehatan dan pendidikan. Eksklusi sosial yang dialami penyandang disabilitas intelektual telah memperkecil kesempatan untuk mengenyam pendidikan dan hal tersebut masih terus berlangsung sampai saat ini.

Penyebab eksklusi sosial dapat terbagi ke dalam kelompok struktur dan kultur. Pola hubungan kekuasaan antara kelompok sosial dan berbentuk komposisi, stratifikasi, dan diferensiasi sosial disebut sebagai struktur sosial. Struktur sosial dapat berupa legalformal seperti kebijakan dan aturan maupun beberapa hal yang tidak formal. Struktur dapat memiliki kekuatan memaksa, memerintah, dan menghambat pada tindakan individu maupun kelompok. Sedangkan kultur merupakan sistem norma, nilai, dan kepercayaan serta kebiasaan-kebiasaan dan adat istiadat yang telah terinternalisasi sehingga membentuk pola perilaku dan sikap anggota masyarakat (Wirutomo, 2013).

Penyebab eksklusi sosial di pendidikan bagi penyandang disabilitas intelektual yang bersumber pada kultur adalah stigma, stereotip, labelisasi, dan prasangka. Stigma merupakan sebuah proses di mana reaksi orang lain merusak identitas seseorang (Goffman, 1963). Labelisasi (labeling), anggapan yang mengarah pada pengembangan stereotip (stereotyping), dan prasangka (prejudice) merupakan manifestasi dari stigma (Link, Bruce G; Phelan, 2001).

\subsection{Eksklusi Sosial Akibat Kultur}

Diskriminasi tidaklah hilang, ia hanya berubah menjadi bentuk yang lebih halus dan semakin tidak terlihat (Barnes, 2010). Para aktor organisasi yang terdiri dari keluarga, sekolah, masyarakat, dan pemerintah memiliki andil yang besar dalam menciptakan eksklusi sosial terhadap penyandang disabilitas intelektual. Beberapa tindakan eksklusi sosial yang disebabkan oleh kultur adalah sebagai berikut:

\subsubsection{Sekolah Enggan Menerima Penyandang Disabilitas Intelektual}

Akibat adanya kebijakan terkait pemenuhan hak penyandang disabilitas maka semakin banyak sekolah di DKI Jakarta dari berbagai jenjang baik jenjang pendidikan dasar maupun pendidikan menengah menerima siswa berkebutuhan khusus termasuk siswa penyandang disabilitas intelektual. Namun semangat yang terbangun adalah keterpaksaan.

“Kita ikut aturan ... tidak boleh nolak," BR, guru SMA Y, 27 Maret 2019.

"Kan ada aturannya ... sekolah tidak boleh menolak ... ya kami terima semampu kami," SJ, wakil kepala sekolah SMK Z, 13 Maret 2019.

Meskipun pemerintah DKI telah mewajibkan semua sekolah menerima peserta didik penyandang disabilitas namun tetap saja dapat ditemui kepala sekolah yang menolak.

“... Sekolah jangan direpotkan, bagaimana sekolah kita mau bagus kalau ditumpangi anak-anak yang seperti itu ", AR kepala SMP X, 11 Maret 2019, 
Penolakan terhadap penyandang disabilitas intelektual tidak hanya terjadi di sekolah reguler yang menyelenggarakan pendidikan inklusif namun juga di sekolah luar biasa.

“... Nah, sekarang Ibu yang SLB ST, istrinya Pak DR itu... Di sini penuh Bu AK, nggak ada lagi..... Apa karena kuota? Juga mungkin dia, karena kuota juga Mbak. Saya juga nggak ngerti,” AK, guru SMP X, 19 Maret 2019.

Hasil wawancara menggambarkan bahwa sekolah masih belum dapat menerima penyandang disabilitas intelektual. Pada akhirnya, anak penyandang disabilitas intelektual akan semakin tereksklusikan di pendidikan karena tidak diterima dimana-mana. Akreditasi sekolah merupakan alasan bagi sekolah reguler untuk menolak. Sekolah luar biasa (SLB) menjadikan "kuota" sebagai alasan untuk tidak menerima anak penyandang disabilitas intelektual.

Sikap keberatan yang memicu eksklusi sosial ternyata terus dialami penyandang disabilitas intelektual walaupun mereka telah bersekolah. Eksklusi sosial terjadi karena guru merasa bahwa anak penyandang disabilitas intelektual di sekolah merupakan tambahan "beban" bagi mereka.

"guru tidak mampu kan karena waktu karena mereka (anak penyandang disabilitas intelektual) memerlukan perhatian lebih karena (mereka) lambat.. kita butuh guru bimbingan khusus (GBK), bapak ibu guru kan (ter)beban(i)..”EW, SMP X, 19 Maret 2019.

Bentuk lain dari eksklusi sosial di sekolah yang dialami oleh penyandang disablitas intelektual adalah pengabaian. Sekolah mengabaikan keberadaan penyandang disabilitas intelektual saat: (1) Sekolah menyamakan layanan yang diberikan kepada semua anak termasuk penyandang disabilitas intelektual; (2) Sekolah tidak memperhitungkan penyandang disabilitas intelektual dalam pengembangan program pendidikan. Sebagai akibatnya, mereka hanya sebatas hadir tanpa ikut dilibatkan dalam proses belajar mengajar di kelas; (3) Sekolah menaikkan siswa penyandang disabilitas atas dasar kasihan dan tidak mau direpotkan.

“... Ah, bodo amat. Yang penting kan naik, naik, naik, biar cepet keluar (dari sekolah sini). Saat itu kan kayak gitu,” AK, guru SMP X, 19 Maret 2019.

Eksklusi sosial yang terjadi di sekolah reguler juga tercermin dari sikap guru yang cenderung membandingkan penyandang disabilitas intelektual dengan penyandang disabilitas yang lain.

"Kalau anak disabilitas intelektual memang agak sulit ya... selama ini anak tunanetra biasanya mereka (kognitifnya) "kenceng" jadi kita tidak begitu bermasalah ...," EW, guru SMP X, 19 Maret 2019.

Eksklusi di pendidikan bagi penyandang disabilitas intelektual terjadi pada saat sekolah tidak dapat menjalankan peran dan fungsinya dengan baik. Sikap guru yang mengabaikan kepentingan penyandang disabilitas intelektual akibat prasangka dan strereotip yang berkembang di pemikiran mereka. Kepala sekolah dan guru yang berkeyakinan bahwa peserta didik penyandang disabilitas adalah peserta didik yang amat sulit untuk dapat dilayani dalam pembelajaran di sekolah. Pandangan tersebut terjadi karena guru berprasangka dan membandingkan peserta didik intelektual disabilitas dengan peserta didik non penyandang disabilitas intelektual.

Guru cenderung lebih menyukai peserta didik penyandang disabilitas fisik dan sensori yang dalam kesehariannya tidak akan menimbulkan banyak kesulitan dan memberikan tambahan beban pekerjaan bagi mereka. Guru hanya melihat bahwa keberadaan peserta didik penyandang disabilitas intelektual merupakan beban berat bagi guru, "mengganggu" proses pembelajaran bagi peserta didik lainnya dan dapat menyebabkan prestasi sekolah menjadi rendah. Rasa kasihan yang tidak pada tempatnya telah menyebabkan pemberian layanan yang seadanya.

\subsubsection{Sikap dan Pandangan Keluarga}

Sikap dan pandangan keluarga yang menghambat berasal dari orang tua pihak terdekat anak penyandang disabilitas intelektual. Tanpa disengaja dan disadari, keluarga terutama 
orang tua anak penyandang disabilitas intelektual telah menjadi pihak pertama yang menciptakan hambatan bagi anak.

Keluarga yang merasa khawatir dan takut cenderung melindungi anaknya yang disabilitas intelektual secara berlebihan (over protective). Sikap tersebut telah membuat anak mereka menjadi semakin tidak berdaya.

"... Yang menjadi kendala kami ya itu tadi, justru yang menjadi masalah banyak salah satunya di orang tua sih ya terlalu (over protective). Yang (membuat) saya berpikir yang ABK adalah yang orang tua," NK, guru SMK Z, 28 Maret 2019.

Sikap rendah diri dan khawatir akan keadaan anaknya yang penyandang disabilitas intelektual telah menyebabkan orangtua (keluarga) selalu merasa was-was. Orang tua takut jika sekolah atau siswa lain meminta anaknya untuk keluar dari sekolah karena kondisinya yang tidak dapat memenuhi harapan sekolah. Orang tua menjadi sensitif dan takut ketika dipanggil oleh sekolah atau guru untuk berkoordinasi. Guru mengeluh karena keluarga atau orang tua dianggap tidak dapat bekerja sama.

Bagi penyandang disabilitas intelektual, keluarga merupakan pihak pertama yang membangun hambatan (barrier). Eksklusi sosial sudah dialami oleh mereka penyandang disabilitas intelektual sejak mereka dilahirkan. Kondisi ini sangat mengejutkan karena ternyata keluarga batihlah yang pertama kali melakukan praktek eksklusi sosial tersebut.

Keluarga seolah merestui tindakan yang dilakukan oleh orang tua. Seorang ibu rela dan tega untuk menggugurkan kandungannya karena sang bayi berpotensi besar menjadi disabilitas. Pada umumnya para orang tua yang melakukan hal tersebut tidak menyadari bahwa telah mengeksklusikan putra/putri mereka yang memiliki hambatan dengan alasan cinta. "... they tend to emphasize the limits of caretaking within an available family structure and concern for a child's potential suffering." (Rapp \& Ginsburg, 2010).

Jika keluarga memutuskan untuk mempertahankan anak yang menyandang disabilitas intelektual, maka keluarga terutama orang tua sering dihantui oleh perasaan bersalah. Perasaan bersalah yang masih sering dialami oleh orang tua penyandang disabilitas intelektual telah memicu sikap rendah diri, terlihat gengsi, dan over protective terhadap anaknya. Tidak hanya itu, keluarga yang memiliki anak penyandang disabilitas intelektual cenderung tertutup.

Persoalan yang dialami keluarga merupakan pemicu terjadinya eksklusi sosial terutama di pendidikan. Oleh karenanya, keluarga membutuhkan dukungan dari sekolah, masyarakat, dan pemerintah. Dukungan tersebut tidak dapat diperoleh jika sekolah, masyarakat, dan pemerintah belum paham tentang disabilitas intelektual sehingga memiliki sikap dan cara pandang yang kurang tepat terhadap penyandang disabilitas intelektual.

\subsubsection{Peran Masyarakat}

Dari hasil wawancara diperoleh gambaran bahwa masyarakat kurang menjalankan fungsinya sebagai media penyebaran informasi. Masih ada orang tua anak penyandang disabilitas tidak tahu cara menjamin pemenuhan hak pendidikan anaknya.

... salah lingkungan juga sebenarnya karena tidak memberikan informasi. Ada SD, SMP (di sana) tapi terbukti dia tidak sekolah," SJ, wakil kepala SMK Z, 13 Maret 2019.

Sikap masyarakat terhadap penyandang disabilitas intelektual ternyata tidak mengalami perubahan dari tahun ke tahun. Penyandang disabilitas intelektual masih berada di urutan paling bawah dan selalu mendapat perlakuan yang negatif. Pada umumnya, sama halnya anggapan yang dimiliki guru, masyarakat merasa lebih nyaman berinteraksi dengan penyandang disabilitas sensori dan fisik dibandingkan bila mereka harus berinteraksi dengan penyandang disabilitas intelektual.

\subsection{Eksklusi Sosial Pendidikan Akibat Struktur}

Demikian kuatnya stigma negatif yang melekat pada penyandang disabilitas intelektual telah membuat mereka terlupakan tidak hanya di masyarakat namun juga di kalangan 
pembuat kebijakan. Oleh para pembuat kebijakan mereka dianggap tidak dapat dididik sehingga mereka selalu disisihkan. Dengan alasan tersebut para pemegang kebijakan melakukan pengabaian terhadap hak-hak pendidikan mereka dengan cara tidak memperhitungkan para penyandang disabilitas intelektual pada saat mereka menyusun perencanaan pendidikan (McKenzie, Pillay, Duvenhage, Du Plessis, \& Jelsma, 2017).

\subsubsection{Kebijakan Bersifat Umum dan Cenderung Diskriminatif}

Secara tidak disadari, pemerintah telah membuat keputusan yang merugikan penyandang disabilitas intelektual terutama mereka yang bersekolah di sekolah reguler penyelenggara pendidikan inklusif. Beberapa keputusan yang mendeskreditkan penyandang disabilitas intelektual antara lain keputusan penerapan full day school dan penetapan capaian siswa hanya berdasarkan nilai akademik.

"Dulu ada program tambahan di siang hari ... sekarang terkendala waktu. Saat ini tidak ada program khusus karena tidak ada waktu,” WE, guru dari SMP X, 19 Maret 2019.

Pada sistem full day school, lama waktu belajar panjang mempersulit siswa penyandang disabilitas intelektual karena dengan demikian guru tidak dapat lagi mengalokasikan waktu untuk memberikan pengayaan bagi mereka setelah jam pembelajaran berakhir.

Keberhasilan yang selalu dimaknai pemerintah sebagai pencapaian akademik yang baik menyebabkan siswa diminta untuk mencapai target akademik tertentu. Hal ini dialami siswa yang berada di sekolah-sekolah menengah pertama dan sekolah menengah atas. Keadaan ini memberatkan siswa penyandang disabilitas intelektual.

“... tingkat SMP ini, untuk di Indonesia ini tuntutannya adalah akademis,” AK, guru dari SMP X, 19 Maret 2019

"Tapi menurut saya, ini menurut saya pribadi ya, untuk anak dengan keterlambatan intelektual itu, keterampilan itu menjadi lebih penting dibanding dengan akademik dan sebagainya," BD, LSM Maju Bersama, 28 Maret 2019.

Pada kenyataannya, kemampuan akademik siswa penyandang disabilitas intelektual tidak bisa dijadikan dasar untuk menentukan program pembelajaran yang dikembangkan bagi penyandang disabilitas intelektual. Bagi siswa penyandang disabilitas intelektual, keterampilan yang memandirikan lebih bermanfaat. Salah seorang informan menyatakan bahwa kebijakan pemerintah DKI terkait pemenuhan aksesibilitas bagi penyandang disabilitas sudah cukup baik. Namun fokus aksesibilitas masih pada penyandang disabilitas fisik dan sensori. Penyandang disabilitas intelektual belum memperoleh cukup perhatian. Salah satu contoh adalah ketiadaan kebijakan yang mengakomodir keberadaan guru atau pedamping bagi penyandang disabilitas intelektual yang memiliki pengetahuan pedagogis yang memadai.

Pemerintah DKI Jakarta telah menerbitkan dua kebijakan yang merupakan kunci bagi pemenuhan hak pendidikan penyandang termasuk penyandang disabilitas intelektual. Peraturan gubernur DKI Jakarta no. 116 tahun 2007 yang diikuti dengan terbitnya surat edaran kepala dinas pendidikan DKI Jakarta no. 119/SE/2016 merupakan dua kebijakan kunci di pemerintahan daerah DKI Jakarta. Kedua aturan ini merupakan cermin dari komitmen pemerintah terhadap penghapusan eksklusi sosial di pendidikan yang dilakukan melalui penyelenggaraan pendidikan inklusif.

Namun regulasi tersebut dinilai belum mampu menjawab permasalahan yang terdapat di sekolah. Pada konteks penyandang disabilitas intelektual, kedua regulasi ini belum memberikan solusi bagaimana memberikan layanan pembelajaran pada peserta didik penyandang disabilitas intelektual di sekolah.

"Sangat tegas untuk regulasi. Mengikuti regulasi, iya. Dalam artian, apa pemerintah sudah memberikan regulasi seperti itu. Tetapi memberikan regulasi, tapi tidak memfasilitasi” AK, guru dari SMP X, 19 Maret 2019. 
Pada kenyataannya, tanpa disadari penyebab eksklusi sosial di pendidikan bagi penyandang disabilitas intelektual justru berasal dari kebijakan yang telah ada. Kebijakan yang ada belum cukup memperhitungkan keberadaan penyandang disabilitas intelektual dan merumuskan layanan yang memadai bagi penyandang disabilitas intelektual bila dibandingkan dengan penyandang disabilitas lainnya (sensori dan fisik). Oleh karenanya tanpa disadari telah terjadi pengabaian hak-hak penyandang disabilitas intelektual di pendidikan.

Kebijakan dan aturan-aturan terkait penyandang disabilitas intelektual yang telah diterbitkan oleh pemerintah DKI Jakarta telah mendorong sekolah untuk menerima siswa penyandang disabilitas tidak terkecuali penyandang disabilitas intelektual. Sebagai salah satu upaya mengikuti kebijakan pemerintah maka sekolah menerapkan labelisasi terhadap penyandang disabilitas intelektual. Tindakan labelisasi diterapkan sekolah karena mereka mencoba menciptakan suasana yang kondusif secara institusi (institutionally condusive setting) (Gabel, Cohen, Kotel, \& Pearson, 2013). Pelabelan dianggap juga sebagai salah satu cara untuk mempermudah mengenali para penyandang disabilitas intelektual. Namun ternyata label yang diberikan kepada peserta didik penyandang disabilitas intelektual di sekolah telah membuat mereka tersisihkan dalam pergaulan. Labeling yang lahir dari kebijakan sekolah merupakan manifestasi dari kebijakan yang masih diskriminatif.

Secara singkat maka dapat digambarkan bagaimana struktur dan kultur berpengaruh terhadap eksklusi sosial di pendidikan yang menyebabkan terhambatnya pemenuhan hak pendidikan penyandang disabilitas intelektual.

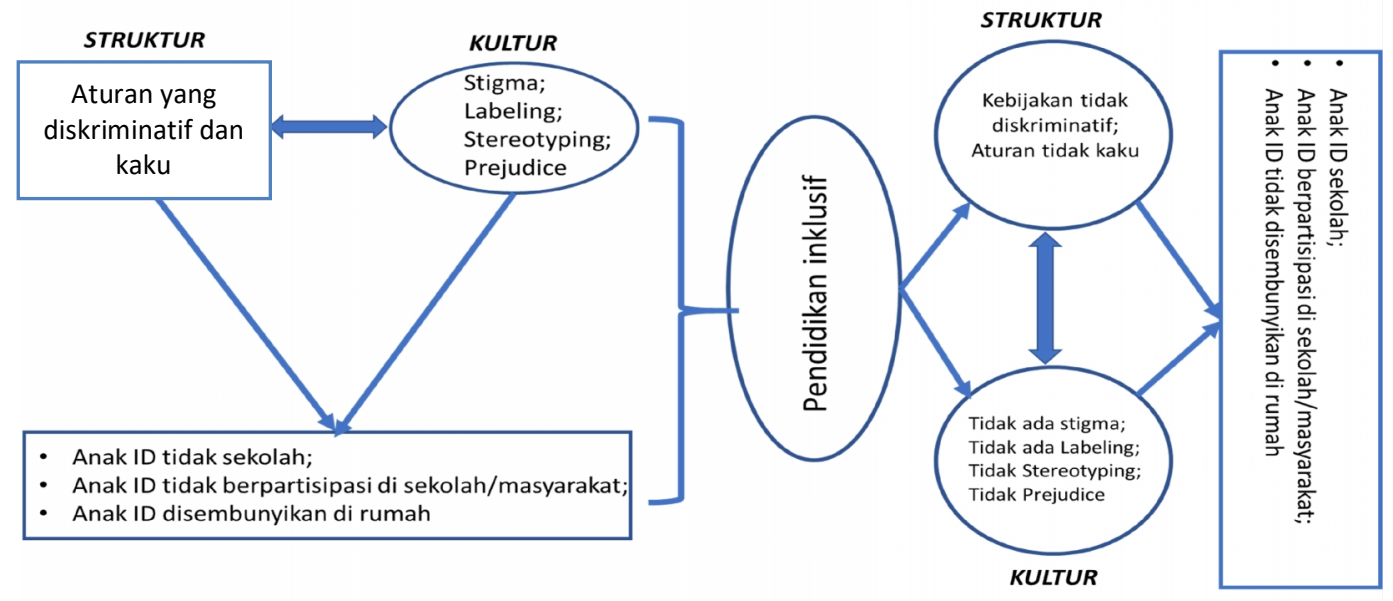

Gambar 1: Hubungan Kultur, Struktur, dan Pendidikan Inklusif.

Hambatan struktur lahir karena pemegang kebijakan belum memiliki pemahaman yang benar tentang disabilitas intelektual sehingga kebijakan ataupun aturan yang ada belum mengakui dan mengakomodir keberadaan penyandang disabilitas intelektual. Sedangkan hambatan kultur tercipta karena adanya stigma, prasangka, stereotip di kalangan pembuat kebijakan, kepala sekolah, guru, peserta didik lain, bahkan keluarga terhadap penyandang disabilitas intelektual.

Kedua hambatan tersebut dapat dihilangkan melalui penyelenggaraan pendidikan inklusif. Pendidikan inklusif diyakini sebagai pilihan yang terbaik untuk menyelesaikan permasalahan eksklusi sosial. Hal ini dikarenakan pendidikan inklusif merupakan pendekatan yang humanis yang membuka kesempatan dan akses di pendidikan bagi penyandang disabilitas tidak terkecuali penyandang disabilitas intelektual.

\section{Model Penyelenggaraan Pendidikan Inklusif Bagi Penyandang Disabilitas Intelektual.}

Salah satu negara bagian di India yang menyelenggarakan pendidikan inklusif bagi penyandang disabilitas intelektual adalah Orissa. Penyelenggaraan pendidikan inklusif bagi 
penyandang disabilitas intelektual yang dilakukan oleh pemerintah Orissa meliputi beberapa hal atau tindakan-tindakan yang penting. Hal atau tindakan yang penting tersebut berada pada dua tataran yaitu kultur dan struktur. Pertama, perubahan kultur yang meliputi perubahan cara pandang pendidik, peserta didik, tenaga kependidikan, orang tua, masyarakat, dan pemerintah serta keterlibatan masyarakat merupakan kunci awal langkah pemenuhan hak pendidikan penyandang disabilitas intelektual. Kedua, struktur terkait kebijakan dan aturan-aturan yang ada meliputi adanya rencana aksi (action plan) yang menekankan pentingnya pengembangan pembelajaran berbasis keluarga (home based learning) serta penetapan batas anak penyandang disabilitas intelektual yang dapat diterima di sekolah inklusif berdasarkan kategori. Penyandang disabilitas intelektual yang dapat bersekolah di sekolah inklusif hanyanya mereka yang masuk dalam kategori ringan. Hal lain yang tidak kalah pentingnya adalah komitmen pemerintah untuk menyediakan guru pembimbing khusus (GPK) ataupun pendamping bagi penyandang disabilitas intelektual di sekolah inklusif.

Kuwait juga merupakan salah satu negara yang mulai menerapkan penyelenggaraan pendidikan inklusif guna pemenuhan pendidikan bagi penyandang disabilitas intelektual. Sama halnya dengan yang dilakukan oleh pemerintah Orissa di India, kegiatan-kegiatan yang dilakukan berfokus kepada perbaikan sikap dan cara pandang guru serta peningkatan kesadaran masyarakat. Di samping itu juga, pemerintah melakukan perbaikan di sisi kebijakan terkait kurikulum dan pengawasan.

Di Indonesia, saat ini belum ada ditemukan model penyelenggaraan pendidikan inklusif yang ditujukan khusus bagi penyandang disabilitas intelektual. Saat ini penyelenggaraan pendidikan inklusi yang diterapkan masih mengacu kepada penyelenggaraan pendidikan inklusif bagi penyandang disabilitas secara umum. Untuk hal ini, pemerintah Indonesia telah menerbitkan pedoman bagi sekolah. Pedoman ini merupakan pedoman umum penyelenggaraan pendidikan inklusif yang diterbitkan oleh Direktorat Pembinaan Sekolah Luar Biasa Direktorat Jenderal Manajemen Pendidikan Dasar dan Menengah Departemen Pendidikan Nasional, Kementerian Pendidikan Indonesia pada tahun 2007. Berdasarkan pedoman ini maka model pendidikan inklusi yang diterapkan di Indonesia merupakan perpaduan antara pendidikan inklusi dan pendidikan terpadu atau yang diperkenalkan sebagai istilah pendidikan inklusif model moderat.

Model yang dikembangkan di Indonesia masih sangat bersifat berfokus kepada pengembangan individu penyandang disabilitas saja tanpa memberikan perhatian lebih terhadap perbaikan lingkungan sekitar. Hal tersebut berbeda dengan model penyelenggaraan pendidikan inklusif yang saat ini dikembangkan oleh pemerintah India dan Kuwait. Dalam konteks pemerintah Indonesia termasuk pemerintah DKI Jakarta, model penyelenggaraan pendidikan inklusif yang dianggap dapat mengatasi masalah eksklusi sosial di pendidikan bagi penyandang disabilitas intelektual berfokus kepada dua pihak yaitu penyandang disabilitas intelektual dan lingkungan sosialnya. Penyelenggaraan pendidikan inklusif dengan model ini akan lebih banyak melibatkan keluarga, sekolah, masyarakat, dan pamerintah daerah sebagai aktor organisasi untuk berperan lebih banyak untuk meniadakan eksklusi sosial di pendidikan bagi penyandang disabilitas intelektual.

Dalam membangun model penyelenggaraan pendidikan inklusif bagi penyandang disabilitas intelektual, beberapa elemen inti yang diperhatikan demi kesuksesan penerapannya (UNESCO, 2005) adalah (1) Tujuan yang jelas dan realistis. Model yang dikembangkan harus memiliki tujuan yang jelas dan realistis; (2) Motivasi. Model yang dikembangkan berdasarkan pada motivasi untuk meniadakan eksklusi sosial yang dialami penyandang disabilitas intelektual; (3) Mengidentifikasi sumber. Selain tujuan dan motivasi, model tersebut juga perlu menemukenali sumber atau modal yang dimiliki. Modal yang dimiliki cukup menentukan keberhasilan model; (4) Merancang dan melaksanakan evaluasi. Agar dapat mengukur keberhasilan model yang diterapkan, maka perlu ditentukan pula strategi evaluasi yang akan diterapkan.

Jika mengacu kepada para aktor, peran, hal-hal yang diupayakan oleh para aktor dan tujuan akhir yang diharapkan, maka model penyelenggaraan pendidikan inklusif bagi 
penyandang disabilitas intelektual yang dapat ditawarkan dapat dilihat dalam skema sebagai berikut:

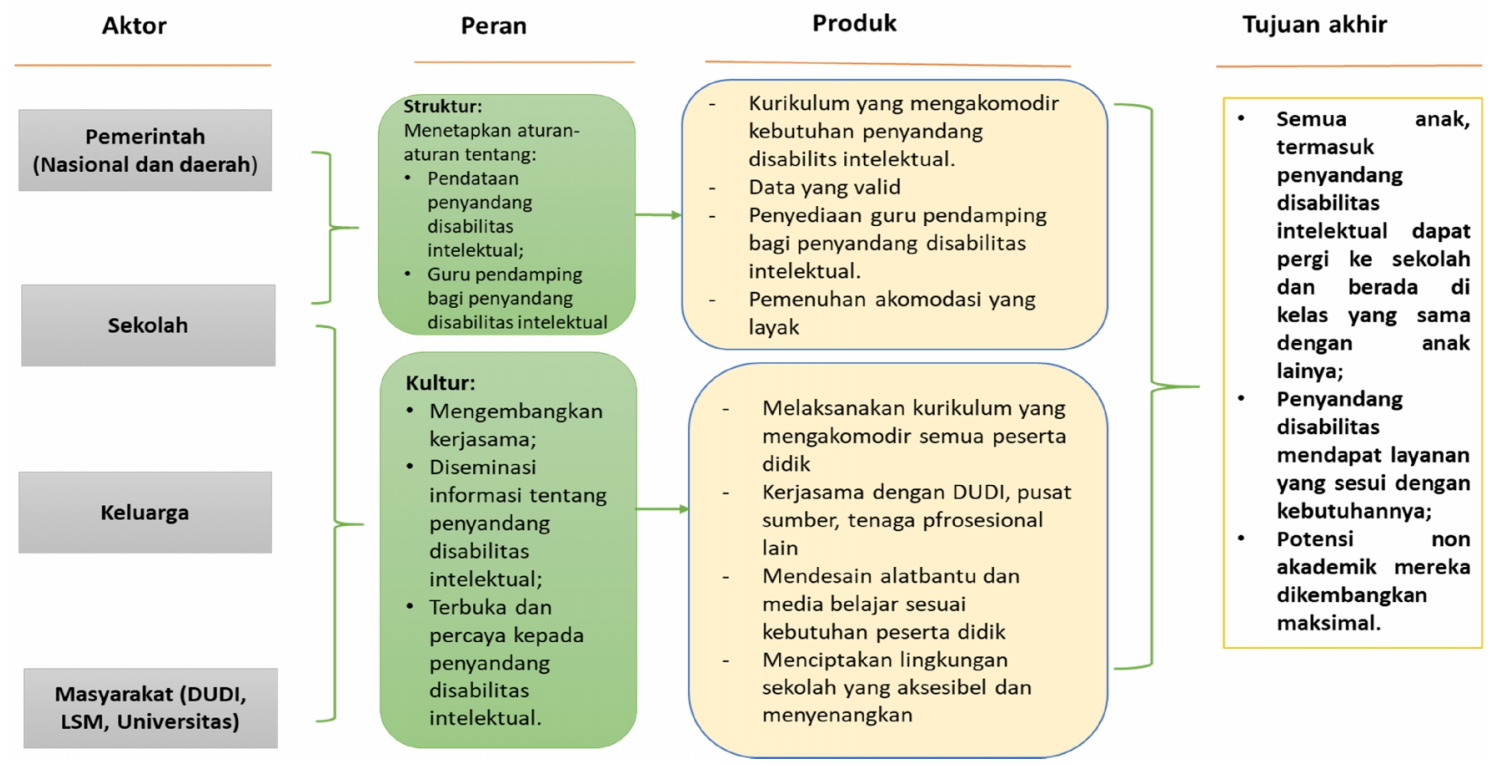

Gambar 2: Model Penyelenggaraan Pendidikan Inklusif Bagi Penyandang Disabilitas Intelektual

Para aktor organisasi yang terlibat adalah pemerintah baik daerah maupun nasional, sekolah, keluarga, dan masyarakat. Pada model ini, pemerintah dan sekolah akan mengambil peran dalam mengembangan kebijakan atau aturan, kepastian data, keberadaan guru pendamping, dan pemenuhan akomodasi yang layak. Sedangkan keluarga, sekolah, dan masyarakat diharapkan dapat saling bekerja sama, memastikan penyebaran informasi tentang penyandang disablitas intelektual, terbuka dan percaya terhadap kemampuan penyandang disabilitas intelektual.

Dengan begitu maka hambatan kultur dan struktur yang ada akan perlahan berkurang. Hambatan kultur yang dimaksud adalah stigma, prasangka (McKenzie et al., 2017), stereotip, labelisasi, dan ruang (Kitchin, 1998), sedangkan kebijakan dan aturan-aturan yang diskriminatif merupakan hambatan secara struktur.

Pada model yang dikembangkan para aktor organisasi tersebut diharapkan dapat mengupayakan layanan yang sesuai kebutuhan dan kemampuan penyandang disabilitas intelektual. Agar layanan yang dapat memberikan sesuai maka pemerintah, sekolah, keluarga, dan masyarakat perlu memiliki pemahaman yang tepat tentang penyandang disablitas intelektual dan pendidikan inklusif. Dengan demikian, pemerintah perlu mengadakan kegiatan seperti pelatihan, sosialisasi, dan kampanye penyadaran publik terkait penyandang disabilitas intelektual dan pendidikan inklusif. Kegiatan-kegiatan ditujukan untuk mengkapasitasi pemerintah, keluarga, sekolah, dan masyarakat.

Dengan perubahan kultur dan struktur, hasil akhir dari penyelenggaraan model pendidikan inklusif ini adalah semakin banyak anak penyandang disabilitas intelektual yang dapat bersekolah dan diakui keberaadaannya di sekolah. Para penyandang disabilitas intelektual tidak hanya difokuskan dalam pengembangan sisi akademik saja namun terlebih khusus dan penting adalah potensi non-akademik atau keterampilan yang dapat dijadikan dasar kemandirian mereka.

\section{Kesimpulan}

Permasalahan eksklusi sosial yang dialami oleh penyandang disabilitas intelektual khususnya di DKI Jakarta kiranya perlu mendapatkan perhatian yang lebih serius. Menyelesaikan masalah eksklusi sosial di pendidikan tidak cukup hanya dengan membangun kultur namun perlu adanya perbaikan dan penguatan struktur. Secara historis, kategori 'disabilitas intelektual' dijadikan sebagai entitas yang terpisah dan 
didefinisikan melalui model medis yang menggunakan label seperti 'cacat pikiran', 'cacat mental', 'abnormal', dan 'terbelakang' (Scior \& Werner, 2016). Akibat pelabelan sering ditemukan sikap negatif, stigma, dan stereotip dari keluarga, sekolah, dan masyarakat terhadap anak penyandang disabilitas intelektual. Label yang dilekatkan kepada penyandang disabilitas intelektual terkadang membawa "keuntungan" namun juga akan selalu memberikan stigma yang merugikan kepada para penyandang disabilitas intelektual (Snoyman \& Aicken, 2011). Sikap dan pemikiran tersebut sangat merugikan anak penyandang disabilitas intelektual.

Stigma terhadap penyandang disabilitas intelektual sangat mempengaruhi terjadinya proses stereotip. Stereotip terhadap penyandang disabilitas intelektual, ada yang bersifat positif namun banyak pula yang bersifat negatif. Dalam penelitiannya, Gilmore, Campbell, \& Cuskelly (2003) menyatakan bahwa masyarakat memiliki sterotip tentang penyandang disabilitas intelektual yang disertai down syndrome sebagai individu yang penyayang dan selalu gembira. Namun pada umumnya sterotip yang terbangun tentang penyandang disabilitas intelektual adalah terbatas di bidang akademik maupun sosial (TJ \& DC, 2005). Stereotip berpengaruh besar terhadap munculnya sikap prasangka (prejudice) dan diskriminasi (Jahoda \& Markova, 2004).

Stigmatisasi tidak hanya merugikan individu penyandang disabilitas intelektual namun juga keluarga. Keluarga dirugikan melalui tiga cara (K. S. and S. Werner, 2016): (1) sikap negatif yang mungkin dimiliki orang lain tentang keluarga seseorang dengan hambatan intelektual, disebut 'stigma kesopanan'; (2) sikap ketakutan bahwa orang lain memandang secara negatif sebagai orang tua atau anggota keluarga dari seseorang dengan hambatan intelektual, disebut sebagai 'antisipasi stigma'; dan (3) dengan menginternalisasi sikap negatif orang lain, disebut sebagai stigma afiliasi. Menurut Elizabeth (2013), prasangka (prejudice) terhadap penyandang disabilitas intelektual juga merupakan salah satu penyebab rendahnya keinginan para guru untuk memenuhi kebutuhan khusus anak penyandang disabilitas intelektual di sekolah.

Stigma, prasangka, dan labelisasi merupakan bagian dari kultur yang telah menyebabkan terjadinya eksklusi sosial di pendidikan bagi penyandang disabilitas tidak terkecuali penyandang disabilitas intelektual. Keberadaan sikap-sikap tersebut di sekolah dan masyarakat DKI Jakarta semakin memperkuat pendapat McKenzie tentang sikap negatif terhadap penyandang disabilitas itelektual yang ada selama ini. Pandangan negatif tersebut pada akhirnya mendorong lahirnya tindakan sekolah dan masyarakat yang memberikan tempat khusus (space) bagi penyandang disabilitas intelektual. Hal ini merupakan bentuk eksklusi dalam "wujud" yang lebih halus (McKenzie et al., 2017).

Penyelenggaraan pendidikan inklusi diyakini sebagai salah satu cara untuk dapat menghilangkan eksklusi sosial di pendidikan di DKI Jakarta. Hal ini dilakukan dengan cara memperkuat kultur dan struktur yang ada saat ini. Dengan menyelenggarakan pendidikan inklusi, pandangan dan perlakuan negatif terhadap penyandang disabilitas intelektual dapat dihilangkan. Hilangnya stigma, labelisasi, prasangka, dan stereotip serta hadirnya kebijakan yang inklusif akan semakin membuka kesempatan dan peluang pemenuhan hak pendidikan penyandang disabilitas terutama penyandang disabilitas intelektual.

Namun tentunya model penyelenggaraan pendidikan inkusif yang dikembangkan perlu disesuaikan dengan kebutuhan penyandang disabilitas dalam hal ini disabilitas intelektual. Penyelenggaraan pendidikan inklusif bagi penyandang disabilitas intelektual akan berhasil jika pengembangan yang terjadi saling bersinergi tidak hanya pada individu penyandang disabilitas intelektual saja namun terlebih pada lingkungan sosial individu tersebut. Model penyelenggaraan pendidikan inklusif dengan pola seperti diatas membutuhkan kultur yang mendukung dan struktur yang kuat menopang.

Struktur yang kuat ditandai dengan hadirnya kebijakan-kebijakan terkait pendidikan yang diterbitkan oleh pemerintah nasional maupun pemerintah DKI Jakarta yang selalu mempertimbangkan keberadaan penyandang disabilitas intelektual 
tidak hanya penyandang disabilitas pada umumnya. Kebijakan-kebijakan yang hadir hendaknya terkait dengan kurikulum yang dipergunakan dan penyediaan guru pendamping bagi siswa penyandang disabilitas intelektual. Keberadaan kurikulum yang sesuai dengan kebutuhan penyandang disabilitas intelektual akan mendorong potensi mereka sehingga stigma negatif atas mereka akan lambat laun menghilang. Label yang dilekatkan kepada mereka sebagai kelompok yang akan selalu bergantung akan lambat laun tereliminir. Kebijakan tentang kurikulum juga akan menghilangkan sikap prasangka guru terhadap penyandang disabilitas intelektual.

Struktur yang kuat terbangun dapat perlahan merubah kultur. Kultur yang mendukung ditandai dengan banyak kesempatan belajar bahkan bekerja yang diperuntukkan juga bagi penyandang disabilitas intelektual. Orang tua yang semakin memiliki kepercayaan diri dan memberikan kesempatan kepada anak mereka untuk dapat menempuh pendidikan sesuai dengan kemampuannya dan para guru yang semakin yakin dalam memberikan layanan yang sesuai dengan kebutuhan siswa penyandang disabilitas intelektual.

Dengan menggunakan model penyelenggaraan pendidikan inklusif ini maka anak penyandang disabilitas akan semakin tergali potensinya dan mandiri serta terhindar dari eksklusi sosial. Pada sisi para pemegang kepentingan yang terlibat terutama pemerintah khususnya pemerintah DKI Jakarta, mereka dapat memastikan pemenuhan hak pendidikan penyandang disabilitas intelektual di pendidikan dan keberhasilan pendidikan untuk semua (Education for All).

\section{Pengakuan}

Sebagian besar informasi dari penelitian ini merupakan naskah yang menjadi bagian dari tesis pada department sosiologi, fakultas ilmu sosial dan ilmu politik Universitas Indonesia. Untuk itu saya ucapkan terima kasih tidak terhingga kepada ibu Francisia Saveria Sika Ery Seda, M.A., Ph. D, selaku dosen pembimbing atas dukungan dan saran beliau. Ucapan terima kasih juga saya ucapkan kepada pimpinan Helen Keller International yang telah mengijinkan dan mendukung saya untuk terus berkiprah dalam dunia pendidikan bagi penyandang disabilitas.

\section{Daftar Pustaka}

Alshemari, H. (2016). Inclusive Education and Students with Intellectual Disabilities (IDs) in the State of Kuwait: Are We Ready? Washington State University.

APA. (2000). American Pediatric Association.

Barnes, C. (2010). A brief History of Discrimination and Disabled People. Routledge.

BPS. (2015). Data Penyandang Disabilitas Intelektual. Jakarta.

Gabel, S. L., Cohen, C. J., Kotel, K., \& Pearson, H. (2013). Intellectual disability and space: Critical narratives of exclusion. Intellectual and Developmental Disabilities, 51(1), 7480. https:// doi.org/ 10.1352/1934-9556-51.01.074

Gilmore, L., Campbell, J., \& Cuskelly, M. (2003). Developmental Expectations, Personality Stereotypes, and Attitudes Towards Inclusive Education: Community and Teacher Views of Down Syndrome. International Journal of Disability, Development and Education, 5O(1), 65-76. https://doi.org/10.1080/1034912032000053340

Goffman, E. (1963). Stigma:Note of the Management of spoiled identity. Lodon: Penguin.

Jahoda, A., \& Markova, I. (2004). Coping with social stigma: People with intellectual disabilities moving from institutions and family home. Journal of Intellectual Disability Research, 48(8), 719-729. https://doi.org/10.1111/j.1365-2788.2003.00561.x

Kemendikbud. (2018). Data Pokok Pendidikan.

Kitchin, R. (1998). "Out of Place", "Knowing One's Place": Space, power and the exclusion of disabled people. Journal of Disability and Society, 13(3), 343-356.

Levitas, R., Pantazis, C., Fahmy, E., Gordon, D., Lloyd, E., \& Patsios, D. (2007). The MultiDimensional Analysis of Social Exclusion. https://doi.org/ 10.1177/1744987110370529

Link, B. G., \& Phelan, J. C. (2001). Conceptualizing stigma. Annual Review of Sociology, 27, 363-385. https://doi.org/10.1146/annurev.soc.27.1.363

McCaughey, T. J., \& Strohmer, D. C. (2005). Prototypes as an Indirect Measure of Attitudes Toward Disability Groups. Rehabilitation Counseling Bulletin, 48(2), 89-99. 
https://doi.org/10.1177/00343552050480020301

McKenzie, J. A., Pillay, S. G., Duvenhage, C.-M., Plessis, E. Du, \& Jelsma, J. M. (2017). Implementation of Educational Provision for Children with Severe to Profound Intellectual Disability in the Western Cape: From Rights to Reality. International Journal of Disability, Development and Education, 64(6), 596-611. https://doi.org/10.1080/1034912X.2017.1313394

Nowicki, E. A., \& Brown, J. D. (2013). "A Kid Way": Strategies for Including Classmates With Learning or Intellectual Disabilities. Intellectual and Developmental Disabilities, 51(4), 253-262. https://doi.org/10.1352/1934-9556-51.4.253

Rapp, R., \& Ginsburg, F. (2010). Enabling Disability: Rewriting Kinship, Reimagining Citizenship. In L. J. David (Ed.), The Disability Studies Reader (3rd editio, pp. 238-253). Routledge.

Roslina, D., \& Rahayu, E. (2018). Peran Pendamping Dalam Meningkatkan Keberfungsian Sosial Penyandang Disabilitas Intelektual Pada Program Pelayanan Jarak Jauh Di Kecamatan Lembang Dan Cililin, Kabupaten Bandung Barat. Sosio Konsepsia, 7(2), 31-44. https://doi.org/10.33007/ska.v7i2.1167

Salmiah, S. (2010). Retardasi Mental. Medan, Sumatera Utara.

Scior, K., \& Werner, S. (2016). Intellectual Disability and Stigma. London: Macmillan Publishers Ltd.

Snoyman, P., \& Aicken, B. (2011). The concept of intellectual disability , and people with intellectual disability in Corrective Services NSW. Australasian Journal of Correctional Staff Development, 1-12.

UNESCO. (1998). Education for All 2000 Bulletin.

UNESCO. (2005). Guidelines for Inclusion: Ensuring Access to Education for All.

UNICEF. (2013). The State of the World's Children 2013: Children with Disabilities. UNICEF.

United Nation. Convention on The Rights of People with Disability (2006).

Walker, A. and Walker, C. (1997). Britain Divided: The Growth of Social Exclusion in the 1980s and 1990s. London: Child Poverty Action Group.

Werner, K. S. and S. (2016). Intellectual Disability and Stigma: Stepping Out from the Margins. Palgrave Macmillan UK.

Werner, S., \& Abergel, M. (2017). What's in a label? The stigmatizing effect of intellectual disability by any other name. Stigma and Health, 3(4), 385-394. https://doi.org/10.1037/sah0000108

Wirutomo, P. (2013). Mencari Makna Pembangunan Sosial: Studi Kasus Sektor Informal di Kota Solo. Masyarakat, Jurnal Sosiologi, 18(1), 101-120. 